\title{
Antibiotics for acute otitis media: Which children are likely to benefit?
}

\author{
Reviewed by: Salma Rawof, MD; Suneel Upadhye, MD, MSc
}

\begin{abstract}
Clinical question
Does the use of antibiotics in children with acute otitis media lead to improved outcome, defined as an improvement in pain, fever or both after 3-7 days?

Article chosen

Rovers MM, Glasziou P, Appelman CL, et al. Antibiotics for acute otitis media: a meta-analysis with individual patient data. Lancet 2006;368:1429-35.

Study objective

To identify subgroups of children with acute otitis media who are likely to benefit from antibiotic treatment. Benefit is defined by an improvement in pain (subjective parental perspective), fever (temperature $>38^{\circ} \mathrm{C}$ ) or both after 3-7 days.
\end{abstract}

\section{BACKGROUND}

Acute otitis media (AOM) is the most common childhood illness for which antibiotics are prescribed., ${ }^{1,2}$ Acute otitis media accounts for $13 \%$ of visits to the emergency department, and 30 million outpatient clinic visits annually, has a peak incidence between 6 and 18 months of age, and is the second most common cause (after upper respiratory infection) for clinic visits among patients under 15 years of age. ${ }^{3}$ Risk factors for AOM include male sex, parental smoking, a family history of middle ear disease, and attendance at day care..$^{2-4}$ Breast feeding is thought to be protective. ${ }^{4}$ The economic burden of AOM in the year 2000 was reported to exceed US\$5 billion. This cost is predominately due to drugs, visits, and procedures such as tympanostomies, mastoidectomies and adenoidectomies in children younger than 24 months. ${ }^{3,5}$

The management challenge in AOM for most clinicians is in determining which children are likely to have a high-risk bacterial etiology, as this impacts significantly the decision to prescribe antibiotics. Bacteria are the most common etiologic agent of AOM (50\%-90\% of isolates). ${ }^{1,6}$ Viruses account for 5\%-25\% of cases, and $16 \%-25 \%$ of cases have no identifiable pathogen. ${ }^{3}$ One study identified both bacteria and viruses in $66 \%$ of isolates. ${ }^{6}$ Antibiotics are commonly used in the management of AOM, although the majority of cases of AOM resolve spontaneously, resulting in the unnecessary use of antibiotics and growing resistance. ${ }^{7}$ Antibiotic use can also result in adverse effects such as diarrhea or vomiting (16\%), and rash (2\%). ${ }^{2}$

Many studies have been conducted to evaluate the effect of antibiotics on AOM outcomes. Meta-analyses of randomized controlled trials comparing antibiotics versus placebo in treating AOM have shown modest, if any, benefits for the clinically important outcomes of pain, fever and suppurative complications. ${ }^{6,8}$ These studies found high aggregate rates of spontaneous resolution in the placebo arms, and only modest incremental benefits in the antibiotics arms.

\section{STUDY DESIGN}

This meta-analysis collected individual patient data from randomized control trials in AOM. The authors screened studies for eligibility based on the following quality criteria: randomization, follow-up and multiple levels of blinding (e.g., patient, caregiver and outcome assessor). A systematic search of the literature identified 19 trials that investigated the effectiveness of antibiotics in children with AOM. However, the authors excluded 9 trials after screening that failed to meet eligibility criteria. Of the 10 eligible trials, 6 research groups provided individual patient data from their trials. 


\section{POPULATION INCLUDED AND STUDIED}

This meta-analysis included individual patient data for 1643 children from 6 of the 10 eligible trials that randomly assigned patients (aged 6 mo to $12 \mathrm{yr}$ ) with AOM into intervention groups. The interventions compared antibiotic treatment with no treatment, and measured pain and fever as primary outcomes.

\section{OUTCOMES MEASURED}

The primary outcome was an extended course of AOM, which was defined as a composite end point of pain, fever or both after 3-7 days. Pain was assessed by a subjective parental record in diary format. Fever was assessed objectively and defined as a temperature of $38^{\circ} \mathrm{C}$ or higher.

\section{RESULTS}

The baseline characteristics of included children were identical in all predictor variable subgroups, as shown in Table 1. The clinical outcomes for included patients are summarized in Table 2. Details of included trials are shown in Table 3 , including the diagnostic criteria for AOM used by each study.

\section{STUDY CONCLUSION}

Predictor variables that showed significant benefit in the primary outcomes were patient age of less than 2 years and bilateral AOM. The number needed to treat (NNT) in a child under 2 years of age was 7 (95\% confidence interval $[\mathrm{CI}]$ 4-14) and was 10 for children older than 2 (95\% CI 6-17). A more significant difference was found in bilateral AOM with an NNT of 5

\begin{tabular}{|c|c|c|c|}
\hline \multirow[b]{2}{*}{ Predictor variable } & \multicolumn{3}{|c|}{ No. (\%) of patients } \\
\hline & $\begin{array}{c}\text { Antibiotics, } \\
n=819\end{array}$ & $\begin{array}{c}\text { Controls, } \\
n=824\end{array}$ & $\begin{array}{c}\text { Total, } \\
n=1643\end{array}$ \\
\hline Age $<2 y r$ & $280(34.2)$ & 287 (34.8) & 567 (34.5) \\
\hline Fever & $282(34.4)$ & 287 (34.8) & $569(40.3)^{*}$ \\
\hline Bilateral AOM & $236(28.8)$ & $220(26.7)$ & $456(34.3) \dagger$ \\
\hline Otorrhea & $51 \quad(6.2)$ & $65 \quad(7.9)$ & 116 (20.9)‡ \\
\hline \multicolumn{4}{|c|}{$\begin{array}{l}\text { AOM = acute otitis media. } \\
{ }^{*} n=1411 \text { because of missing data from some trials. } \\
\text { t } n=1328 \text { because of missing data from some trials. } \\
\neq n=555 \text { because of missing data from some trials. }\end{array}$} \\
\hline
\end{tabular}

(95\% CI 4-9), and unilateral AOM carried an NNT of $17(95 \%$ CI $8-\infty)$. Because the upper boundary of the 95\% CI for the unilateral group approaches infinity, it is conceivable that there may be no meaningful benefit in this group. In contrast, when the 2 independent predictor variables are combined (children $<2 \mathrm{yr}$ with bilateral $\mathrm{AOM}$ ), the NNT is 4 and the $\mathrm{CI}$ is narrow (95\% CI 3-7). Values, both significant and nonsignificant, for the other combinations are shown in Table 2.

\section{COMMENTARY}

The results of this study indicate that there are specific subgroups of children with AOM who are more likely to benefit from antibiotic treatment. The most significant single predictor of benefit is the presence of bilateral AOM. Less powerful individual predictors are patient age of under 2 years and the presence of otorrhea. The presence of both age under 2 years and bilateral AOM strongly predicts benefit.

This study helps clinicians hone their approach to AOM by targeting those children who are most likely to respond to antibiotics, while helping to limit prescribing to avoid risks of side effects or possible contribution to local antibiotic resistance.

Other studies support the notion of delaying or withholding antibiotics for children with probable viral AOM. A Cochrane review by Glasziou and colleagues ${ }^{8}$ pooled 8 trials (2287 children) and found that there was no benefit from treatment in pain reduction during the first 24 hours, and only a $7 \%$ pain reduction at 2 days with antibiotics $(\mathrm{NNT}=15)$. They further found that

Table 2. Predictor variables and outcomes

\begin{tabular}{lcc}
\hline & $\begin{array}{c}\text { Primary outcome of interest (pain, } \\
\text { fever or both after 3-7 days) }\end{array}$ \\
\cline { 2 - 3 } Predictor variable(s) & RR $(95 \% \mathrm{Cl})$ & $\mathrm{NNT}$ \\
\hline Age $<2 \mathrm{yr}$ & $0.77(0.68-0.89)$ & 7 \\
Age $\geq 2 \mathrm{yr}$ & $0.86(0.80-0.93)$ & 10 \\
Bilateral AOM & $0.72(0.62-0.84)$ & 5 \\
Unilateral AOM & $0.92(0.85-1.00)$ & $\mathrm{NS}$ \\
Otorrhea present & $0.52(0.37-0.73)$ & 3 \\
Otorrhea absent & $0.80(0.70-0.92)$ & 8 \\
Age $<2$ yr + bilateral AOM & $0.64(0.62-0.80)$ & 4 \\
Age $<2$ yr + unilateral AOM & $0.92(0.76-1.11)$ & $\mathrm{NS}$ \\
Age $\geq 2 \mathrm{yr}+$ bilateral AOM & $0.84(0.70-1.02)$ & $\mathrm{NS}$ \\
Age $\geq 2$ yr + unilateral AOM & $0.92(0.85-1.01)$ & $\mathrm{NS}$ \\
\hline AOM $=$ acute otitis media; Cl = confidence interval; NNT = number needed to treat; \\
NS = not significant result/NNT not calculated; RR = relative risk.
\end{tabular}


Table 3. Expanded characteristics of included randomized trials

\begin{tabular}{|c|c|c|c|c|c|c|}
\hline Study & $\begin{array}{l}\text { No. of } \\
\text { patients }\end{array}$ & $\begin{array}{l}\text { Participant } \\
\text { age }\end{array}$ & Intervention & $\begin{array}{l}\text { Duration of } \\
\text { intervention, } d\end{array}$ & Outcomes & $\begin{array}{c}\text { Diagnostic criteria for } \\
\text { AOM }\end{array}$ \\
\hline Appelman et al. ${ }^{9}$ & 121 & $6 \mathrm{mo}-12 \mathrm{yr}$ & $\begin{array}{l}\text { Amoxicillin }(8.3 \mathrm{mg} / \mathrm{kg} \text { ) } \\
\text { with clavulanate } \\
\text { (2.08 } \mathrm{mg} / \mathrm{kg}) \mathrm{v} \text {. placebo } \\
\text { (weight-related dosing } \\
\text { as per original paper) }\end{array}$ & 7 & $\begin{array}{l}\text { - Pain after } 3 \mathrm{~d} \\
\text { - Fever after } 3 \mathrm{~d} \\
\text { - Otorrhoea } \\
\text { - Otoscopy and } \\
\text { tympanometry after } \\
1 \mathrm{mo}\end{array}$ & $\begin{array}{l}\text { - Otalgia } \\
\text { - Otoscopic signs of } \\
\text { middle ear infection }\end{array}$ \\
\hline Burke et al. ${ }^{10}$ & 232 & $3 \mathrm{mo}-10 \mathrm{yr}$ & $\begin{array}{l}\text { Amoxicillin (125 mg tid) } \\
\text { v. placebo }\end{array}$ & 7 & $\begin{array}{l}\text { - Symptoms noted by } \\
\text { parents (including } \\
\text { fever and ear pain) } \\
\text { - Home visits by } \\
\text { researcher after } 24 \mathrm{~h} \\
\text { and } 5-7 \mathrm{~d} \\
\text { - Otoscopy and } \\
\text { tympanometry after } \\
1 \text { and } 3 \text { mo }\end{array}$ & $\begin{array}{l}\text { - Ear pain } \\
\text { - Abnormal ear drum }\end{array}$ \\
\hline Damoiseaux et al. ${ }^{11}$ & 240 & $6 \mathrm{mo}-2 \mathrm{yr}$ & $\begin{array}{l}\text { Amoxicillin } 40 \mathrm{mg} / \mathrm{kg} / \mathrm{d} \\
\text { tid v. placebo }\end{array}$ & 10 & $\begin{array}{l}\text { - Symptoms at day } 4 \\
\text { assessed by a GP } \\
\text { (including fever and } \\
\text { earpain) } \\
\text { - Otoscopy and } \\
\text { tympanometry after } \\
6 \text { wk and } 3 \text { mo }\end{array}$ & $\begin{array}{l}\text { - Otoscopic signs of } \\
\text { AOM } \\
\text { OR } \\
\text { - Otorrhea } \\
\text { AND } \\
\text { - one of: } \\
\text { - fever } \\
\text { - recent earache } \\
\text { - general malaise } \\
\text { - recent irritability }\end{array}$ \\
\hline Little et al. ${ }^{12}$ & 315 & $6 \mathrm{mo}-10 \mathrm{yr}$ & $\begin{array}{l}\text { Immediate } v \text {. delayed } \\
\text { treatment } \\
\text { Amoxicillin } 125 \mathrm{mg} \text { in } \\
5 \mathrm{~mL} \text {, tid, } 100 \mathrm{~mL} \text { in } \\
\text { total }\end{array}$ & 7 & $\begin{array}{l}\text { - Symptoms noted by } \\
\text { parents (including } \\
\text { fever and ear pain) } \\
\text { - Absence from } \\
\text { school } \\
\text { - } \text { Consumption of } \\
\text { paracetamol }\end{array}$ & $\begin{array}{l}\text { - Otalgia } \\
\text { - Otoscopic } \\
\text { evidence of acute } \\
\text { inflammation of } \\
\text { the ear drum }\end{array}$ \\
\hline Le Saux et al. ${ }^{13}$ & 512 & $6 \mathrm{mo}-5 \mathrm{yr}$ & $\begin{array}{l}\text { Amoxicillin }(60 \mathrm{mg} / \mathrm{kg} \\
\text { daily) v. placebo }\end{array}$ & 10 & $\begin{array}{l}\text { - Telephone follow-up } \\
\text { at day } 1,2,3 \text {, and } \\
\text { between } 10 \text { and } 14 \mathrm{~d} \\
\text { (including fever) } \\
\text { - Tympanometry at } 1 \\
\text { and } 3 \text { mo }\end{array}$ & $\begin{array}{l}\text { - Ear pain } \\
\text { - Fever }\left(>38^{\circ} \mathrm{C}\right)\end{array}$ \\
\hline McCormick et al. ${ }^{14}$ & 223 & $6 \mathrm{mo}-12 \mathrm{yr}$ & $\begin{array}{l}\text { Immediate } v \text {. delayed } \\
\text { treatment } \\
\text { Amoxicillin } 90 \text { mg/kg/d } \\
\text { bid, max } 1500 \text { mg/d, } \\
\text { for } 10 \mathrm{~d}\end{array}$ & 10 & $\begin{array}{l}\text { - Symptoms noted by } \\
\text { parents (including } \\
\text { fever and ear pain) } \\
\text { - Nasopharyngeal } \\
\text { carriage } \\
\text { - Adverse events } \\
\text { - Absence from } \\
\text { school } \\
\text { - Tympanometry after } \\
12 \text { and } 30 \text { d }\end{array}$ & $\begin{array}{l}\text { - Symptoms of ear } \\
\text { infection - pain, } \\
\text { fever, irritability } \\
\text { - Otoscopic } \\
\text { evidence of AOM }\end{array}$ \\
\hline
\end{tabular}


$80 \%$ of cases spontaneously resolved in this time frame with conservative care. However, the authors found benefits in pain and fever outcomes from days 3 to 7 with antibiotic treatment. This is consistent with observed benefits of treatment in the subject study, although there were no observations of outcomes at the 1-2 day point, as was analyzed in the review by Glasziou and colleagues. There was a significant increase in vomiting, diarrhea and rash in the treatment groups. The authors recommended that in developed countries, where the risk of mastoiditis is low, early antibiotic treatment is not warranted. ${ }^{8}$

This Cochrane review by Glasziou and coauthors included 4 studies that were excluded from the subject study, and all found benefits with antibiotic usage on days $3-7$, but none on days $1-2$. However, there were no subgroup analyses performed to look at the age group under 2 years old, although 3 of the 4 studies did enroll patients below this threshold. Also, no subgroups were analyzed on the basis of predictor variables included here (i.e., bilateral v. unilateral AOM, and the presence of otorrhea). This study also included new information from 2 trials that had not been published at the time of the Cochrane review; however, it did include the individual patient data that had been excluded from the Cochrane review as it was not a placebo-controlled trial and was therefore unsuitable for traditional meta-analysis models employed by the Cochrane Collaboration.

Studies such as those cited above suggest that a delayed approach to antibiotics usage in healthy children with AOM seems to have no adverse clinical consequences, with resolution rates similar to those for children who are treated conservatively with analgesics. This individual patient data meta-analysis helps clinicians identify those children under 2 years old with bilateral disease for whom the use of antibiotics will likely be of benefit. The choice to treat or not is influenced by many other factors including clinician and parent preference, but it is reasonable to educate parents with lower risk children on the benefits of a trial of conservative management. The pediatric guidelines in the United States advise a treatment duration of 10 days for children less than 2 years old or with severe disease, and 5-7 days for children older than 6 years and/or with mild to moderate disease (severity not clearly defined, strength of recommendations not stated). ${ }^{2}$

A number of published commentaries have examined the implications of this new work. Mattila ${ }^{15}$ has commented that the results of this study have the potential to reduce initial antibiotic prescribing by more than half on the first visit, with significant financial and public health benefits to follow. In another report, Matilla ${ }^{16}$ noted that some of the original trials excluded children with severe symptoms or who were "too unwell." Finally, Walling ${ }^{17}$ also reinforced that these study results support the treatment of bilateral disease for all ages $(\mathrm{NNT}=4$ for $<2 \mathrm{yr}$; NNT $=9$ for $2-12 \mathrm{yr})$ to reduce pain, fever or both at the $3-7$ day point. It is evident from Table 3 that there is substantial clinical heterogeneity with respect to age groups studied, antibiotics chosen and dosing, as well as the treatment duration, all of which create challenges when trying to pool data and reach robust conclusions.

Another study by Rovers and colleagues ${ }^{18}$ using the same data set, identified independent baseline predictors for what could develop into a prolonged course of AOM: 1$)$ age ( $<2$ yr or $\geq 2 \mathrm{yr}$ ), 2) fever (yes or no) and $3)$ bilateral AOM. The authors did not comment on what diagnostic criteria were employed to establish a diagnosis of AOM, or whether this was consistently applied across the 6 included studies. As shown in Table 3, however, all studies incorporated otalgia and otoscopic findings for the diagnosis of AOM diagnosis, an approach that is likely congruent with the practice of most emergency physicians.

\section{CONCLUSION}

This unique study identified a subgroup of children with a diagnosis of AOM for whom antibiotics are warranted, namely those with bilateral AOM (regardless of age), children under 2 years of age with either unilateral or bilateral AOM, and children with otorrhea. The use of individual patient data provided information that cannot be ascertained when traditional meta-analysis models are used to pool data at the study level, and the appropriate screening of children for specific predictor variables for treatment would benefit from further refinement.

Competing interests: None declared.

Keywords: antibiotics, acute otitis media, individual patient data meta-analysis

\section{REFERENCES}

1. Delage G, Speert D. Antibiotic management of acute otitis media. Paediatr Child Health 1998;3:265-7.

2. American Academy of Pediatrics, Subcommittee on Manage- 
ment of Acute Otitis Media. Diagnosis and management of acute otitis media. Pediatrics 2004;113:1451-65.

3. Spiro DM, Arnold DH. The concept and practice of a waitand-see approach to acute otitis media. Curr Opin Pediatr 2008;20:72-8.

4. Pfaff JA, Moone GP. Chapter 71: Otolaryngology. In: Marx J, Hockberger R, Walls R, editors. Rosen's emergency medicine: concepts and clinical practice. 6th ed. St. Louis (MO): Mosby; 2006.

5. Bondy J, Berman S, Glazner J, et al. Direct expenditures related to otitis media diagnoses: extrapolations from a pediatric Medicaid cohort. Pediatrics 2000;105:E72.

6. Ruohola A, Meurman O, Nikkari S, et al. Microbiology of acute otitis media in children with tympanostomy tubes: prevelances of bacteria and viruses. Clin Infect Dis 2006;43: 1417-22.

7. Rosenfeld RM, Vertrees JE, Carr J, et al. Clinical efficacy of antimicrobial drugs for acute otitis media: meta-analysis of 5400 children from thirty-three randomized trials. 7 Pediatr 1994;124:355-67.

8. Glasziou PP, Del Mar CB, Sanders SL, et al. Antibiotics for acute otitis media in children. Cochrane Database Syst Rev 2004;(Issue 1):CD0002 19 10.1002/14651858.CD000219.pub2.

9. Appelman CL, Claessen JQ, Touw-Otten FW, et al. Coamoxiclav in recurrent acute otitis media: placebo controlled study. BMJ 1991;303:1450-2.

10. Burke P, Bain J, Robinson D, et al. Acute red ear in children: controlled trial of non-antibiotic treatment in general practice. BMJ 1991;303:558-62.

11. Damoiseaux RA, van Balen FA, Hoes AW, et al. Primary care based randomised, double blind trial of amoxicillin versus placebo for acute otitis media in children aged under 2 years. BMJ 2000;320:350-4.

12. Little P, Gould C, Williamson I, et al. Pragmatic randomised controlled trial of two prescribing strategies for childhood acute otitis media. BMJ 2001;322:336-42.

13. Le Saux N, Gaboury I, Baird M, et al. A randomized, doubleblind, placebo-controlled noninferiority trial of amoxicillin for clinically diagnosed acute otitis media in children 6 months to 5 years of age. CMAJ 2005;172:335-41.

14. McCormick DP, Chonmaitree T, Pittman C, et al. Nonsevere acute otitis media: a clinical trial comparing outcomes of watchful waiting versus immediate antibiotic treatment. Pediatrics 2005;115:1455-65.

15. Mattila PS. Antibiotics in childhood acute otitis media. Lancet 2006;368:1397-8.

16. Mattila PS. Antibiotics are effective in acute otitis media in children younger than 2 years with bilateral disease and in children with both otorrhea and acute otitis media. 7 Pediatr 2007;150:562.

17. Walling AD. Antibiotics for children with otitis media. Am Fam Physician 2007;75:1061.

18. Rovers MM, Glasziou P, Appelman PB, et al. Predictors of pain and/or fever at 3 to 7 days for children with acute otitis media not initially treated with antibiotics: a meta-analysis of individual patient data. Pediatrics 2007;119:579-85.

Correspondence to: Dr. Suneel Upadhye, Division of Emergency Medicine, Rm. 2Q15b, 1200 Main St. W., Hamilton ON L8N 3Z5; upadhyes@mcmaster.ca 